\title{
Influence of Ramadan-type fasting on enzymes of carbohydrate metabolism and brush border membrane in small intestine and liver of rat used as a model
}

\author{
Neelam Farooq, Shubha Priyamvada, N. A. Arivarasu, Samina Salim, Farah Khan and \\ Ahad Noor Khan Yusufi* \\ Department of Biochemistry, Faculty of Life Sciences, Aligarh Muslim University, Aligarh, 202002, UP, India \\ (Received 6 February 2006 - Revised 3 July 2006 - Accepted 17 July 2006)
}

\begin{abstract}
During Ramadan, Muslims the world over abstain from food and water from dawn to sunset for a month. We hypothesised that this unique model of prolonged intermittent fasting would result in specific intestinal and liver metabolic adaptations and hence alter metabolic activities. The effect of Ramadan-type fasting was studied on enzymes of carbohydrate metabolism and the brush border membrane of intestine and liver from rat used as a model. Rats were fasted $(12 \mathrm{~h})$ and then refed $(12 \mathrm{~h})$ daily for $30 \mathrm{~d}$, as practised by Muslims during Ramadan. Ramadan-type fasting caused a significant decline in serum glucose, cholesterol and lactate dehydrogenase activity, whereas inorganic phosphate increased but blood urea $\mathrm{N}$ was not changed. Fasting resulted in increased activities of intestinal lactate $(+34 \%)$, isocitrate $(+63 \%)$, succinate $(+83 \%)$ and malate $(+106 \%)$ dehydrogenases, fructose 1,6-bisphosphatase $(+17 \%)$ and glucose-6-phosphatase $(+22 \%)$. Liver lactate dehydrogenase, malate dehydrogenase, glucose-6-phosphatase and fructose 1,6-bisphosphatase activities were also enhanced. However, the activities of glucose-6-phosphate dehydrogenase and malic enzyme fell significantly in the intestine but increased in liver. Although the activities of alkaline phosphatase, $\gamma$-glutamyl transpeptidase and sucrase decreased in mucosal homogenates and brush border membrane, those of liver alkaline phosphatase, $\gamma$-glutamyl transpeptidase and leucine aminopeptidase significantly increased. These changes were due to a respective decrease and increase of the maximal velocities of the enzyme reactions. Ramadan-type fasting caused similar effects whether the rats fasted with a daytime or night-time feeding schedule. The present results show a tremendous adaptation capacity of both liver and intestinal metabolic activities with Ramadan-type fasting in rats used as a model for Ramadan fasting in people.
\end{abstract}

Ramadan fasting: Carbohydrate metabolism: Intestine: Liver: Brush border membrane enzymes

The digestion and absorption of food components are major functions of the intestinal mucosa. These functions are dramatically altered by dietary status, including fasting, restricted energy intake and other dietary manipulations (Budhoski et al. 1982; Mayhew, 1987; Dou et al. 2001; Martins et al. 2001). Short-term fasting for a few days causes a significant decrease in glucose degradation with a concomitant increase in its production in the intestine and other tissues (Shen \& Mistry, 1979; Farooq et al. 2004), whereas refeeding fasted rats resulted in a reversal of these effects (Buts et al. 1990).

Ramadan fasting is a unique model of fasting that is quite different from widely studied total fasting or starvation (Malhotra et al. 1989; Nomani et al. 1989; Cheah et al. 1990). During the Islamic month of Ramadan, which lasts for 29 or $30 \mathrm{~d}$ each year, millions of Muslims all over the world observe total abstention from food and water from dawn to sunset. Food and water is, however, permitted ad libitum between sunset and dawn (Husain et al. 1987; Toda \& Morimoto, 2000). Hence, Ramadan fasting is in fact repeated cycles of fasting followed by refeeding every day and night for about $30 \mathrm{~d}$.

Ramadan fasting in man results in increased serum lipids, uric acid, urea (Gumaa et al. 1978; Fedail et al. 1982; Hallack \& Nomani, 1988; Nomani et al. 1989), NEFA and 3-OH butyrate, and a decrease in blood glucose, lactate and pyruvate (Malhotra et al. 1989; Nomani et al. 1989), indicating alterations in metabolic activities. The changes in urine volume, osmolarity, total solutes and ions $\left(\mathrm{Na}^{+}, \mathrm{K}^{+}\right)$and urea produce no adverse health effects on renal function (Cheah et al. 1990; Leiper et al. 2003). Basal metabolism slows down (Husain et al. 1987), whereas body fat is utilised efficiently during Ramadan fasting (El Ati et al. 1995). HDL cholesterol increases whereas LDL cholesterol decreases with Ramadan fasting (Adlouni et al. 1997; Benli Aksungar et al. 2005). Owing to different dietary habits and physical activities, both a gain (Frost \& Pirani, 1987) and a loss (El Ati et al. 1995), and sometimes no change (Husain et al. 1987), in body weight have been reported after Ramadan fasting.

As millions of Muslims (young and old) have for centuries abstained from food and water in the daytime during the Islamic month of Ramadan, it seems important to examine the influence of this fasting schedule on human health, especially with respect to nutrition and energy metabolism. Although studying human biology is ideal, such studies are neither feasible nor ethical. Thus, the vast majority of current biomedical research is conducted using laboratory animals such as rats. In the present study, Ramadan-type fasting (RTF) was mimicked

Abbreviations: BBM, brush border membrane; G6PDH, glucose-6-phosphate dehydrogenase; GGTase, $\gamma$-glutamyl transpeptidase; ICDH, isocitrate dehydrogenase; LAP, leucine aminopeptidase; LDH, lactate dehydrogenase; MDH, malate dehydrogenase; RTF, Ramadan-type fasting; SDH, succinate dehydrogenase.

* Corresponding author: Professor A. N. K. Yusufi, fax +91 571 2706002, email yusufi@lycos.com 
experimentally in rats used as a model for Ramadan fasting in man. Rats were fasted $(12 \mathrm{~h})$ and then refed (12h) daily for $30 \mathrm{~d}$, as practised by Muslims during the month of Ramadan. We hypothesised that RTF would result in specific intestinal and liver adaptations and alter metabolic activities.

To address this hypothesis, the influence of RTF on enzymes of carbohydrate metabolism and brush border membrane (BBM) in rat intestine and liver was determined. The activities of enzymes involved in glucose oxidation (e.g. lactate dehydrogenase (LDH), isocitrate dehydrogenase (ICDH), succinate dehydrogenase $(\mathrm{SDH})$, malate dehydrogenase $(\mathrm{MDH})$ ) and its production (e.g. fructose 1,6-bisphosphatase, glucose-6-phosphatase) markedly increased in mucosal and liver homogenates in RTF compared with control rats. However, the enzymes of the $\mathrm{BBM}$ involved in the terminal digestion and/or absorption of nutrients decreased in intestine but increased in liver.

\section{Materials and methods}

Chemicals

Sucrose, p-nitrophenyl phosphate, sodium succinate, NADH and $\mathrm{NADP}^{+}$were purchased from Sigma Chemical Co. (St Louis, MO, USA). All other chemicals used were of analytical grade and were purchased from either Sigma Chemical Co. or Sisco Research Laboratory (Mumbai, India).

\section{Experimental design}

Unlike people, rats are nocturnal feeders, and it may be considered unphysiological to fast them in the daytime. It has, however, been reported that the rhythmic pattern of certain intestinal enzymes disappears in rats when they are fasted (for up to $5 \mathrm{~d}$ ) on a daytime or night-time feeding schedule, and instead increases or changes either in anticipation of or in the presence of food (Saito et al. 1976). It has also been reported that a monosodium-glutamate-induced increase in alkaline phosphatase activity was not a consequence of actual day/night intake variations but due to a more general effect of monosodium glutamate characterised by neurohormonal and metabolic disturbances (Martinkova et al. 2000).

Considering the importance of Ramadan fasting, the effect of RTF was determined initially in rats that were fasted for $12 \mathrm{~h}$ followed by $12 \mathrm{~h}$ refeeding with either a daytime or a night-time feeding schedule for $30 \mathrm{~d}$. The rats were killed at the end of last fast in the morning (day-fasters) or in the evening (night-fasters) after a stabilisation period of $10-12 \mathrm{~h}$. It was noted that rats rushed to eat and drink immediately when food or water was given to them at the end of fasting period and then ate intermittently during the refeeding (12 h) time.

The results summarised in Table 1 shows that day/night RTF resulted in similar alterations in serum glucose, cholesterol, blood urea $\mathrm{N}$, inorganic phosphate and LDH activity. As there was no significant difference between the respective controls, the values were pooled to make one control value. Various tissue enzymes also showed a similar pattern irrespective of day/night fasting-refeeding variations (see Results). It appeared that rats, irrespective of whether they were fasted by day or by night, showed adaptations similar to those observed earlier (Saito et al. 1976). Therefore a comprehensive effect of RTF was determined, as described later, by a daytime fasting $(12 \mathrm{~h})$ followed by a night-time refeeding $(12 \mathrm{~h})$ schedule; the results are compared with the nocturnal fasting schedule where appropriate.

Young adult Wistar rats weighing $135-155 \mathrm{~g}$, fed with a standard pellet diet (Amrut Laboratories, Pune, India) and water ad libitum, were conditioned for 1 week before the start of the experiment. All animals were kept under conditions that prevented them from experiencing unnecessary pain and discomfort according to the guidelines approved by Ethical Committee. The rats were separated into two groups. One group was put on RTF (12 h fasting/12 h refeeding) for $30 \mathrm{~d}$. The other group received their diet and water ad libitum both day and night and were used as a control. After $30 \mathrm{~d}$, the rats were killed under light ether anaesthesia. The liver and entire small intestine, from the ligament of Trietz to the end of ileum, was removed. The intestines were washed by flushing them with ice-cold buffered saline ( $1 \mathrm{mmol} / \mathrm{l} \mathrm{Tris-HCl,} 9 \mathrm{~g} / \mathrm{l} \mathrm{NaCl}, \mathrm{pH} 7 \cdot 4)$. The weights of the animals were recorded at the beginning and end of the experiment.

\section{Preparation of homogenate}

The washed intestines were slit in the middle, and the entire mucosa was gently scraped with a glass slide and weighed. A $15 \mathrm{~g} / 1$ homogenate of this mucosa was prepared in icecold $100 \mathrm{mmol} / \mathrm{l}$ Tris-HCl, $\mathrm{pH} 7 \cdot 4$, using a Potter-Elvehejem homogeniser (Remi Motors, Mumbai, India) by passing five

Table 1. Effect of daytime and night-time Ramadan-type fasting on serum parameters

(Mean values with their standard errors and percentage change from control values (\%) for 12 rats per group)

\begin{tabular}{|c|c|c|c|c|c|c|c|c|c|c|c|c|c|c|c|c|c|c|}
\hline \multirow[b]{2}{*}{ Group } & \multicolumn{3}{|c|}{$\begin{array}{l}\text { Blood urea N } \\
(\mathrm{mg} / \mathrm{dl})\end{array}$} & \multicolumn{3}{|c|}{ Glucose (mg/dl) } & \multicolumn{3}{|c|}{ Cholesterol (mg/dl) } & \multicolumn{3}{|c|}{$\begin{array}{l}\text { Inorganic } \\
\text { phosphorus } \\
(\mu \mathrm{mol} / \mathrm{ml})\end{array}$} & \multicolumn{3}{|c|}{$\begin{array}{c}\text { Alkaline } \\
\text { phosphatase } \\
\text { (units/dl) }\end{array}$} & \multicolumn{3}{|c|}{$\begin{array}{c}\text { Lactate } \\
\text { dehydrogenase } \\
\text { (units } / \mathrm{ml} \text { ) }\end{array}$} \\
\hline & Mean & SE & $\%$ & Mean & SE & $\%$ & Mean & SE & $\%$ & Mean & SE & $\%$ & Mean & SE & $\%$ & Mean & SE & $\%$ \\
\hline $\begin{array}{l}\text { Control } \\
\text { Ramadar }\end{array}$ & $\begin{array}{l}26 \cdot 82 \\
\text {-type fas }\end{array}$ & $\begin{array}{c}0.53 \\
\text { sting }\end{array}$ & & $147 \cdot 228$ & $1 \cdot 26$ & & 123.087 & $0 \cdot 62$ & & $2 \cdot 35$ & 0.09 & & $8 \cdot 84$ & $0 \cdot 22$ & & $2 \cdot 67$ & 0.26 & \\
\hline Day & $26 \cdot 09$ & 0.47 & -3 & $102 \cdot 984$ & $2 \cdot 97^{*}$ & -30 & $86 \cdot 91$ & $0.82^{*}$ & -29 & $2 \cdot 73$ & $0.07^{\star}$ & +16 & $11 \cdot 72$ & $0.21^{*}$ & +33 & $1 \cdot 84$ & $0.11^{*}$ & -31 \\
\hline Night & $26 \cdot 85$ & 0.88 & & $110 \cdot 84$ & $2 \cdot 58^{\star}$ & -25 & $78 \cdot 85$ & $0.52^{*}$ & -36 & 3.03 & $0.02^{*}$ & +29 & $9 \cdot 17$ & $0.07^{*}$ & +4 & 1.82 & $0.27^{*}$ & -32 \\
\hline
\end{tabular}

*Mean values were significantly different from control at $P<0.05$ or higher degree of significance by group $t$ test and ANOVA. 
pulses. The homogenate was centrifuged at $2000 \mathrm{~g}$ at $4{ }^{\circ} \mathrm{C}$ for $10 \mathrm{~min}$ to remove cell debris, and the supernatant thus obtained was used for assaying enzymes of carbohydrate metabolism. Liver homogenates were similarly prepared and analysed simultaneously. Aliquots of these homogenates were saved and kept at $-20^{\circ} \mathrm{C}$ until analysis.

\section{Preparation of brush border membrane}

BBM was prepared at $4{ }^{\circ} \mathrm{C}$ using differential precipitation by $\mathrm{CaCl}_{2}$ (Kessler et al. 1978). Mucosa scraped from 4-5 washed intestines was used for each BBM preparation. This was homogenized in $50 \mathrm{mmol} / \mathrm{l}$ mannitol, $2 \mathrm{mmol} / \mathrm{l}$ Tris- $\mathrm{HCl}$ buffer, $\mathrm{pH} 7 \cdot 5$, in a glass homogeniser (Wheaton, IL, USA) with five complete strokes. The homogenate was then subjected to high-speed Ultra-Turrex Kunkel (Janke \& Kunkel GmbH \& Co. KG, Staufen, Germany) homogenation for three strokes of $15 \mathrm{~s}$ each with an interval of $15 \mathrm{~s}$ between each stroke. Solid $\mathrm{CaCl}_{2}$ was added to the homogenate to a final concentration of $10 \mathrm{mmol} / \mathrm{l}$, and the mixture stirred for $20 \mathrm{~min}$ on ice. The homogenate was centrifuged at $2000 \mathrm{~g}$ in a J2-21 Beckman centrifuge (J2 MI; Beckman lnstruments, Palo Alto, CA, USA), and the supernatant was then recentrifuged at $352000 \mathrm{~g}$ for $30 \mathrm{~min}$. The pellet was resuspended in $50 \mathrm{mmol} / \mathrm{l}$ sodium maleate buffer, $\mathrm{pH} 6.8$, with four passes by a loose-fitting Dounce homogeniser (Wheaton) in a $15 \mathrm{ml}$ corex tube and centrifuged at $352000 \mathrm{~g}$ for $20 \mathrm{~min}$. The outer white fluffy pellet of BBM was resuspended in a small volume of sodium maleate buffer.

The membrane preparations were purified several magnitudes as the specific activities of the BBM enzymes were increased 7-10-fold compared with the homogenate. Aliquots of homogenates (after high-speed homogenisation) and BBM thus prepared were saved and stored at $-20^{\circ} \mathrm{C}$ until further analysis for the BBM enzymes sucrase, alkaline phosphatase and $\gamma$-glutamyl transpeptidase (GGTase).

\section{Enzyme assays}

The activities of marker enzymes in the homogenate and BBM fraction were determined by standard methods. The activity of alkaline phosphatase was measured by the method of Kempson et al. (1979) using p-nitrophenyl phosphate as a substrate, whereas sucrase was assayed by the method of Bernfeld (1955). GGTase was measured by the method of Glossmann \& Neville (1972) and leucine aminopeptidase (LAP) by the method of Goldmann et al. (1976). The Michaelis Menton constant $\left(K_{\mathrm{m}}\right)$ and maximal velocity of the enzyme reaction $\left(V_{\max }\right)$ were determined by assaying these enzymes at various substrate concentrations $(0 \cdot 6-5.0 \mathrm{mmol} / \mathrm{l}$ for alkaline phosphatase, $5-160 \mathrm{mmol} / \mathrm{l}$ for sucrase, $0 \cdot 1-0.4 \mathrm{mmol} / \mathrm{l}$ for LAP) and analysing the data by Lineweaver-Burk plot. Protein concentrations in BBM preparations and homogenates were determined by the method of Lowry et al. (1951) as modified by Yusufi et al. (1983).

The activities of LDH, MDH, glucose-6-phosphate dehydrogenase (G6PHD), malic enzyme and ICDH, involved in the oxidation of NADH or reduction of $\mathrm{NADP}^{+}$, were determined by measuring extinction changes at $340 \mathrm{~nm}$ in a spectrophotometer (Cintra 5; GBC Scientific Equipment Pty, Victoria, Australia) using $3.0 \mathrm{ml}$ assay mixture in a $1 \mathrm{~cm}$ cuvette at room temperature $\left(28-30{ }^{\circ} \mathrm{C}\right)$. The net reaction rate was measured by the difference between the extinction values obtained prior to the addition of substrate and the values for the actual enzymic reaction following addition of the substrate. Appropriate blanks, in which the substrate was added after stopping the reaction, were run simultaneously.

All enzyme activities were measured under conditions in which enzyme reaction rates were linear with respect to incubation time and protein concentration using the method mentioned against each enzyme: LDH, E.C. 1·1·1.27 (Kornberg, 1955); MDH, E.C. 1·1.1.37 (Meyer et al. 1948); G6PDH, E.C. $1 \cdot 1 \cdot 1.49$ (Shonk \& Boxer, 1964); SDH, E.C. 1·3.99.1 (Szczepanska-Konkel et al. 1987); ICDH, E.C.1·1·1.42 (Ochoa, 1955a); malic enzyme, E.C. 1·1·1·40 (Ochoa, 1955b). Glucose-6-phosphatase E.C. 3·1.3.9 and fructose-1,6-bisphosphatase E.C $3 \cdot 1 \cdot 3 \cdot 11$ were assayed by the method of Shull et al. (1956). The inorganic phosphate liberated was measured by the method of Tausky \& Shorr (1953).

\section{Analysis of serum parameters}

The serum samples were deproteinated with $3 \%$ trichloroacetic acid in a ratio of 1:3 v/v. The samples were centrifuged at $2000 \mathrm{~g}$ (Remi centrifuge, India) for $10 \mathrm{~min}$. The protein-free supernatant was used to estimate inorganic phosphate by the method of Tausky \& Shorr (1953). Total serum cholesterol was estimated directly in serum samples by the method of Zlatkis et al. (1953). Urea was measured by the method of Fingerhut et al. (1966); glucose was estimated by o-toluidine method using kit from Span diagnostics (Surat, India).

\section{Definition of unit}

One unit of enzyme activity is the amount of enzyme required for the formation of $1 \mu \mathrm{mol}$ product/h under specified experimental conditions. Specific activity is enzyme units/mg protein.

\section{Statistical analysis}

Results are expressed as means with their standard errors for at least three separate experiments. There were two groups of rats in each experiment: control and RTF group. Each sample of BBM and homogenate was prepared by pooling tissues from $4-5$ rats. The data are representative of $12-15$ rats per group per experiment. Where appropriate, statistical evaluation was conducted by group $t$ test and ANOVA.

\section{Results}

The effect of RTF with $12 \mathrm{~h}$ daytime fasting and $12 \mathrm{~h}$ nighttime refeeding or vice versa for $30 \mathrm{~d}$ was studied in detail by assessing some serum parameters as well as the activities of certain enzymes from liver and small intestinal mucosa of rats that were involved in terminal digestion, absorption and carbohydrate metabolism. 
Table 2. Effect of Ramadan-type fasting on body and mucosal weight of rats

(Mean values with their standard errors for three different experiments with four rats per group and change from control values (\%))

\begin{tabular}{|c|c|c|c|c|c|c|c|c|c|c|}
\hline \multirow[b]{2}{*}{ Group } & \multicolumn{3}{|c|}{ Body weight (g) } & \multicolumn{3}{|c|}{$\begin{array}{l}\text { Mucosal weight } \\
\text { (g/intestine) }\end{array}$} & \multicolumn{3}{|c|}{$\begin{array}{l}\text { Total mucosal protein } \\
\qquad(\mathrm{mg})\end{array}$} & \multirow[b]{2}{*}{ Mucosal weight:body weight ratio } \\
\hline & Mean & SE & $\%$ & Mean & SE & $\%$ & Mean & SE & $\%$ & \\
\hline Control & $245 \cdot 83$ & $7 \cdot 67$ & & $4 \cdot 3$ & 0.47 & & $1240 \cdot 51$ & 150 & & 0.017 \\
\hline Ramadan-type fasting & 226.92 & 8.66 & -8 & 3.32 & 0.54 & -23 & 989.38 & 98 & -20 & 0.014 \\
\hline
\end{tabular}

The initial mean body weight was 145.95 (SE 7.75)g for $n 24$ rats.

Effect of Ramadan-type fasting on serum parameters in daytime and night-time fasting conditions

As shown in Table 1, an effect of RTF was observed on various serum parameters during a daytime compared with nighttime fasting schedule. Serum glucose, cholesterol and LDH activity significantly lowered, whereas inorganic phosphate increased under both the daytime and night-time fasting schedule. Blood urea $\mathrm{N}$ was not changed. The activity of serum alkaline phosphatase was, however, significantly increased with daytime fasting but only slightly increased with nighttime fasting.

\section{Effect of Ramadan-type fasting on body and mucosal weight of} rats

The young adult rats used in the study showed a significant increase in body weight in both the control $(+68 \%)$ and the fasted $(+55 \%)$ rats compared with the weight recorded at the start of the experiment (145.97 (SE 7.75) g). The gain in body weight at the end of $30 \mathrm{~d}$ fasting period was slightly but not significantly lower in the RTF than the control rats. The mucosal weight was also lowered (-22\%; Table 2$)$.

Effect of Ramadan-type fasting on brush border membrane enzymes in mucosal homogenates and isolated brush border membrane

RTF resulted in significant decrease in the activities of alkaline phosphatase, GGTase and sucrase in mucosal homogenates and in the isolated BBM preparations (Table 3).
The enzyme activities similarly increased (7-10-fold) in the membrane preparations compared with respective values for the homogenate in both the control and RTF rats, indicating that the quality of membranes prepared by the procedure was similar for control and RTF rats. The specific activities of alkaline phosphatase, GGTase and sucrase all fell significantly (by approximately $25 \%$ ) in the homogenates. However, alkaline phosphatase activity decreased to greater extent $(-38 \%)$ than the activities of GGTase $(-25 \%)$ and sucrase $(-20 \%)$ in BBM preparations. In a preliminary experiment, it was observed that the activities of both alkaline phosphatase $(-25 \%)$ and sucrase $(-20 \%)$ declined similarly in daytimefasted as well in night-time-fasted rats (data not shown). The kinetic parameters $\left(K_{\mathrm{m}}, V_{\max }\right)$ of alkaline phosphatase and sucrase were also determined by assaying the enzymes in BBM preparations at different substrate concentrations. The results summarised in Table 4 show that the decrease in the activity of both alkaline phosphatase and sucrase caused by RTF was due mainly to a decrease in the $V_{\max }$ of the enzyme rather than to changed values of the Michaelis Menton constant $\left(K_{\mathrm{m}}\right)$.

Effect of Ramadan-type fasting on enzymes of carbohydrate metabolism in rat intestine

The specific activities of various enzymes involved in carbohydrate metabolism were determined in mucosal homogenates of control and RTF rats (daytime-fasted) after $30 \mathrm{~d}$ fasting. The activity of $\mathrm{LDH}$, a representative of anaerobic glycolysis, markedly increased $(+34 \%)$ with RTF (LDH activity being similarly enhanced by night-time fasting). However, the

Table 3. Effect of Ramadan-type fasting on the activities of alkaline phosphatase, $\gamma$-glutamyl transpeptidase and sucrase in the mucosal homogenates and brush border membrane preparations

(Mean values with their standard errors for specific activities ( $\mu \mathrm{mol} / \mathrm{mg}$ protein per $\mathrm{h}$ ) for three different experiments with their respective change from control values (\%))

\begin{tabular}{|c|c|c|c|c|c|c|c|}
\hline \multirow[b]{2}{*}{ Group } & \multicolumn{3}{|c|}{ Homogenate } & \multicolumn{3}{|c|}{ Brush border membrane } & \multirow[b]{2}{*}{$\times$ Enrichment } \\
\hline & Mean & SE & $\%$ & Mean & SE & $\%$ & \\
\hline \multicolumn{8}{|l|}{ Alkaline phosphatase } \\
\hline Control & $7 \cdot 46$ & 0.05 & & $56 \cdot 48$ & 0.72 & & $7 \cdot 6$ \\
\hline Ramadan-type fasting & $5 \cdot 50$ & $0 \cdot 01^{*}$ & -26 & $34 \cdot 86$ & $5 \cdot 36^{*}$ & -38 & $6 \cdot 3$ \\
\hline \multicolumn{8}{|l|}{$\gamma$-Glutamyl transpeptidase } \\
\hline Control & $4 \cdot 30$ & $0 \cdot 14^{\star}$ & & 38.50 & 0.55 & & 9 \\
\hline Ramadan-type fasting & $3 \cdot 25$ & $0.02^{*}$ & -24 & $28 \cdot 75$ & $1 \cdot 68^{*}$ & -25 & $8 \cdot 8$ \\
\hline \multicolumn{8}{|l|}{ Sucrase } \\
\hline Control & $55 \cdot 20$ & 0.09 & & $540 \cdot 63$ & $12 \cdot 5$ & & $9 \cdot 7$ \\
\hline Ramadan-type fasting & $42 \cdot 00$ & $1 \cdot 64^{*}$ & -24 & $433 \cdot 80$ & $5 \cdot 70^{\star}$ & -20 & $10 \cdot 32$ \\
\hline
\end{tabular}

* Means were significantly different from control at $P<0.05$ or higher degree of significance by group $t$ test and ANOVA. 
Table 4. Effect of Ramadan fasting on the kinetic parameters of alkaline phosphatase and sucrase

(Means values with their standard errors for three different experiments with their respective change from control values (\%))

\begin{tabular}{|c|c|c|c|c|c|}
\hline \multirow[b]{2}{*}{ Group } & \multicolumn{2}{|c|}{$\begin{array}{c}K_{\mathrm{m}} \\
\left(\times 10^{-3} \mathrm{moL} / \mathrm{L}\right)\end{array}$} & \multicolumn{3}{|c|}{$\begin{array}{c}V_{\max }(\mu \mathrm{mol} / \mathrm{mg} \\
\text { protein per } \mathrm{h})\end{array}$} \\
\hline & Mean & SE & Mean & SE & $\%$ \\
\hline \multicolumn{6}{|l|}{ Alkaline phosphatase } \\
\hline Control & 0.90 & 0.04 & $41 \cdot 66$ & $3 \cdot 27$ & \\
\hline Ramadan-type fasting & 0.90 & 0.01 & $32 \cdot 25$ & $1 \cdot 27^{\star}$ & -23 \\
\hline \multicolumn{6}{|l|}{ Sucrase } \\
\hline Control & $41 \cdot 6$ & 0.01 & 333 & $30 \cdot 24$ & \\
\hline Ramadan-type fasting & 41.6 & 0.06 & 222 & $18 \cdot 32^{*}$ & -33 \\
\hline
\end{tabular}

$K_{\mathrm{m}}$ (Michaelis Menton constant) and $V_{\max }$ (maximal velocity of enzyme reaction) were determined in brush border membrane preparations.

${ }^{*}$ Means were significantly different from control at $P<0.05$ or higher degree of significance by group $t$ test and ANOVA.

activities of $\mathrm{ICDH}, \mathrm{SDH}$ and $\mathrm{MDH}$, enzymes of glucose oxidation, profoundly increased after the $0 \mathrm{~d}$ RTF period. The activity of ICDH increased significantly $(+63 \%)$, whereas the activities of SDH $(+83 \%)$ and $\mathrm{MDH}(+106 \%)$ increased to much greater extent compared with control values (Table 5).

The effect of RTF on the activities of gluconeogenic enzymes fructose 1,6-bisphosphatase and glucose-6-phosphatase was also determined. The activities of these enzymes were also enhanced during RTF compared with values in the control rats, although the increase was smaller compared with that seen with the enzymes involved in glycolysis (LDH) and the tricarboxylic acid cycle (ICDH, SDH, MDH). The activities of G6PDH (hexose monophosphate shunt) and malic enzyme, which play important role in reducing anabolic pathways by supplying NADPH, were also studied. In contrast to the enzymes of glucose oxidation and production, the activities of both G6PDH
$(-33 \%)$ and malic enzyme $(-36 \%)$ significantly declined in rat mucosa after RTF (Table 6).

Effect of Ramadan-type fasting on enzymes of carbohydrate metabolism in rat liver homogenates

The effect of RTF in both a daytime and night-time fasting schedule are shown in Table 7. The specific activities of $\mathrm{LDH}$ and $\mathrm{MDH}$, enzymes involved in glucose degradation, profoundly increased in both fasting schedules. The activities of gluconeogenic enzymes glucose-6-phosphatase and fructose 1,6-bisphosphatase also markedly enhanced after RTF in the liver homogenates irrespective of day/night variations in the feeding schedule. The effect was more prominent in the liver than in intestinal enzymes. In contrast to intestine, where the activities of G6PDH and malic enzyme declined, the activities of these enzymes profoundly increased to a similar extent in both fasting conditions. Compared with intestinal enzymes, the activities of alkaline phosphatase, GGTase and LAP were significantly increased in the liver homogenates (Table 8) from both daytime-fasted and night-time-fasted RTF rats. Kinetic analysis showed that the increase in LAP activity $(+71 \%)$ was mainly due to an alteration in the $V_{\max }$ of LAP activity (RTF: 3.33 (SE 0.08) v. control: 1.96 (SE 0.02), whereas $K_{\mathrm{m}}$ was unchanged (data not shown).

\section{Discussion}

The main purpose of the present study was to determine the influence of RTF on certain enzymes involved in carbohydrate metabolism and terminal digestion in the intestine and liver of rats used as a model of human Ramadan fasting. The present results in part support our hypothesis that RTF results in specific intestinal and liver metabolic adaptations. Indeed,

Table 5. Effect of Ramadan type fasting on the specific activities of lactate dehydrogenase (LDH), isocitrate dehydrogenase (ICDH), succinate dehydrogenase $(\mathrm{SDH})$ and malate dehydrogenase $(\mathrm{MDH})$ in homogenates of intestinal mucosa

(Mean values with their standard errors for specific activities $(\mu \mathrm{mol} / \mathrm{mg}$ protein per $\mathrm{h}$ ) for three different experiments with their respective change from control values (\%))

\begin{tabular}{|c|c|c|c|c|c|c|c|c|c|c|c|c|}
\hline \multirow[b]{2}{*}{ Group } & \multicolumn{3}{|c|}{$\mathrm{LDH}$} & \multicolumn{3}{|c|}{$\mathrm{ICDH}$} & \multicolumn{3}{|c|}{ SDH } & \multicolumn{3}{|c|}{$\mathrm{MDH}$} \\
\hline & Mean & SE & $\%$ & Mean & SE & $\%$ & Mean & SE & $\%$ & Mean & SE & $\%$ \\
\hline Control & 89.75 & 6.35 & & 0.140 & 0.009 & & 0.258 & 0.04 & & $85 \cdot 27$ & 5.35 & \\
\hline Ramadan-type fasting & 120 & $5 \cdot 26^{*}$ & +34 & 0.228 & $0.013^{*}$ & +63 & 0.471 & $0.03^{*}$ & +83 & $175 \cdot 71$ & $10 \cdot 31^{*}$ & +106 \\
\hline
\end{tabular}

* Means were significantly different from control at $P<0.05$ or higher degree of significance by group $t$ test and ANOVA.

Table 6. Effect of Ramadan-type fasting on the specific activities of fructose 1,6-bisphosphatase, glucose-6-phosphatase (G6Pase), glucose-6-phosphate dehydrogenase (G6PDH) and malic enzyme in homogenates of intestinal mucosa

(Mean values with their standard errors for specific activities ( $\mu \mathrm{mol} / \mathrm{mg}$ protein per $\mathrm{h}$ ) for three different experiments with their respective change from control values (\%))

\begin{tabular}{|c|c|c|c|c|c|c|c|c|c|c|c|c|}
\hline \multirow[b]{2}{*}{ Group } & \multicolumn{3}{|c|}{$\begin{array}{c}\text { Fructose 1,6- } \\
\text { bisphosphatase }\end{array}$} & \multicolumn{3}{|c|}{ G6Pase } & \multicolumn{3}{|c|}{ G6PDH } & \multicolumn{3}{|c|}{ Malic enzyme } \\
\hline & Mean & SE & $\%$ & Mean & SE & $\%$ & Mean & SE & $\%$ & Mean & SE & $\%$ \\
\hline Control & 0.47 & 0.01 & & 0.98 & 0.01 & & 0.323 & 0.011 & & 0.473 & 0.017 & \\
\hline Ramadan-type fasting & 0.57 & $0.02^{*}$ & +21 & $1 \cdot 15$ & $0.04^{*}$ & +17 & 0.216 & $0.012^{*}$ & -33 & 0.305 & $0.036^{*}$ & -36 \\
\hline
\end{tabular}

${ }^{*}$ Means were significantly different from control at $P<0.05$ or higher degree of significance by group $t$ test and ANOVA. 
the activities of enzymes belonging to various metabolic pathways, for example glycolysis, the tricarboxylic acid cycle and gluconeogenesis, profoundly increased in both the intestine and liver with RTF.

In general, a $30 \mathrm{~d} 12 \mathrm{~h}$ fasting/ $12 \mathrm{~h}$ feeding schedule was associated with a steady gain in body weight in both control $(+68 \%)$ and fasted $(+55 \%)$ young adult rats compared with their starting weights (Table 2). At the end of $30 \mathrm{~d}$ period, however, body weight was slightly $(-8 \%)$ but insignificantly lower in RTF compared with control rats, as has previously been observed in some studies on people (Hallack \& Nomani, 1988; Adlouni et al. 1997, 1998; Maislos et al. 1998; Yucel et al. 2004). The loss of body weight in human subjects has been attributed to either dehydration or loss of body fat during the course of fasting (Roky et al. 2004). The lowering of serum glucose, cholesterol and LDH activity in rats is in partial agreement with the reported decrease in blood glucose, lactate and pyruvate in people after Ramadan fasting (Fedail et al. 1982; Hallack \& Nomani, 1988; Malhotra et al. 1989).

The results of the present study demonstrate that the enzymes involved in glucose degradation and production were significantly enhanced in both the mucosa and the liver (Tables 5-7). Anaerobic glycolysis, compared with oxidative metabolism, has been shown to be the major source of energy in the rat intestine (Hubscher \& Sherrat, 1962). The marked increase in $\mathrm{ICDH}, \mathrm{SDH}$ and $\mathrm{MDH}$ together with LDH activity in the present study, however, suggests that oxidative metabolism in addition to glycolysis becomes involved in increased energy production during prolonged intermittent RTF. Increased fatty acid oxidation (El Ati et al. 1995) may result in enhanced activities of enzymes in the tricarboxylic acid cycle. The activities of G6PDH and malic enzyme, which act to produce NADPH, were differentially altered by RTF. Although the activities of these enzymes significantly declined in the intestine, they were profoundly increased in the liver. Increased NADPH thus produced at least in the liver may have supported many reducing anabolic reactions needed during prolonged intermittent fasting.

The underlying mechanism by which RTF may cause alterations in liver and intestinal metabolic activities seems the composite effects of fasting and refeeding. Fasting is known to produce extensive morphological as well as biochemical changes in the small intestine and liver (Dou et al. 2001; Martins et al. 2001); these include decreased mucosal weight, a reduction in the number and length of microvilli and hence a lowering of the total surface area of the villi and microvilli (Geyra et al. 2001). Refeeding, in contrast, causes a reversal of these effects (Butzner \& Gall, 1990).

Furthermore, the activities of certain enzymes involved in carbohydrate metabolism decrease after fasting (Anderson \& Zakim, 1970; Budhoski et al. 1982; Farooq et al. 2004) and are restored upon refeeding (Stifel et al. 1968, 1969; Shakespeare et al. 1969; Kotler et al. 1982). In contrast, gluconeogenesis is known to increase with fasting and decrease upon refeeding. A rapid degradation of various proteins and enzymes has also been reported by fasting, whereas refeeding results in increased protein/enzyme synthesis (Holt \& Yeh, 1992; Boza et al. 1999). The profound increase in the activities of the enzymes of glycolysis, of the tricarboxylic acid cycle and to some extent of gluconeogenesis by RTF might be due to an enhanced synthesis of these enzymes resulting from repeated $12 \mathrm{~h}$ fasting $/ 12 \mathrm{~h}$ 
Table 8. Effect of daytime and night-time Ramadan-type fasting on the specific activities of alkaline phosphatase, $\gamma$-glutamyl transpeptidase and leucine aminopeptidase in liver homogenate

(Mean values with their standard errors for specific activities ( $\mu \mathrm{mol} / \mathrm{mg}$ protein per $\mathrm{h}$ ) for three different experiments with their respective change from control values (\%))

\begin{tabular}{|c|c|c|c|c|c|c|c|c|c|}
\hline \multirow[b]{2}{*}{ Group } & \multicolumn{3}{|c|}{ Alkaline phosphatase } & \multicolumn{3}{|c|}{$\gamma$-Glutamyl transpeptidase } & \multicolumn{3}{|c|}{ Leucine aminopeptidase } \\
\hline & Mean & $\mathrm{SE}$ & $\%$ & Mean & SE & $\%$ & Mean & SE & $\%$ \\
\hline Control & 1.94 & 0.25 & & 1.37 & 0.03 & & $2 \cdot 81$ & 0.14 & \\
\hline \multicolumn{10}{|c|}{ Ramadan-type fasting } \\
\hline Day & $2 \cdot 70$ & $0.27^{*}$ & +39 & $4 \cdot 31$ & $0.21^{*}$ & +215 & 4.87 & $0 \cdot 14^{*}$ & +73 \\
\hline Night & 3.05 & $0.31^{*}$ & +57 & 3.52 & $0.08^{*}$ & +157 & 4.63 & $0.10^{*}$ & +64 \\
\hline
\end{tabular}

${ }^{*}$ Means were significantly different from control at $P<0.05$ or higher degree of significance by group $t$ test and ANOVA.

refeeding for $30 \mathrm{~d}$. The respective increase or decrease in the activities of alkaline phosphatase, GGTase, LAP and/or sucrase in liver and intestine caused by RTF was found to be due to alterations in the $V_{\text {max }}$ rather than $K_{\mathrm{m}}$ values. These observations also indicate adaptive but specific alterations in protein/enzyme synthesis. The other regulatory mechanisms might be activated by repeated cycles of a $30 \mathrm{~d}$ fasting/refeeding schedule. Elevated serum thyroid hormone levels, as observed in human subjects during Ramadan fasting, might be one of such factors responsible for enhanced metabolic activity (Fedail et al. 1982).

It has been reported that short-term fasting followed by refeeding gave rise to a disappearance of circadian activity and that the alterations observed were actually produced in anticipation of food, rather than in its presence, by specific adaptative mechanisms (Saito et al. 1976) similar to the learning reflexes put forward long ago by Pavlov. It seems reasonable to suggest that rats can be used as a model of human Ramadan fasting because of the similar alterations observed in some blood parameters in rats and reported in man, and also because of similar metabolic changes observed in the daytime and night-time fasting schedules.

We therefore conclude that RTF in rats results in specific adaptive changes in the metabolic activities of both the intestine and the liver. The increased activities of enzymes involved in the degradation as well as the production of glucose suggest that RTF enhances nutrition and energy metabolism. The results provide useful information of significant clinical importance on adaptations to unusual eating habits with restricted energy intake.

\section{Acknowledgements}

The Council of Scientific and Industrial Research, New Delhi, India, is acknowledged for its award of a Research Associate fellowship to N. F. Financial support to the department from the University Grant Commission and the Department of Science and Technology, and a research grant (SO/SO/B-93/ 89) from the Department of Science and Technology to A. N. K. Y. is also gratefully acknowledged.

\section{References}

Adlouni A, Ghalim N, Benslimane A, Lecerf JM \& Saile R (1997) Fasting during Ramadan induces a marked increase in high-density lipoprotein cholesterol and decrease in low-density lipoprotein cholesterol. Ann Nutr Metab 41, 242-249.
Anderson JW \& Zakim D (1970) The influence of alloxan-diabetes and fasting on glycolytic and gluconeogenic enzyme activities of rat intestinal mucosa and liver. Biochim Biophys Acta 201, 236-241.

Benli Aksungar F, Eren A, Ure S, Teskin O \& Ates G (2005) Effects of intermittent fasting on serum lipid levels, coagulation status and plasma homocysteine levels. Ann Nutr Metab 49, 77-82.

Bernfeld P (1955) $\alpha$ and $\beta$ Amylases. In Methods in Enzymology, vol. 1, pp. 149-151 [SP Colowick and NO Kaplan, editors]. New York: Academic Press.

Boza JJ, Moennoz D, Vuichoud J, Jarret AR, Gaudard-de-Weck D, Fritsche R, Donnet A, Schiffrin EJ, Perruisseau G \& Ballevre O (1999) Food deprivation and refeeding influence growth, nutrient retention and functional recovery of rats. J Nutr 129, $1340-1346$.

Budhoski L, Challis RA \& Newsholme EA (1982) Effects of starvation on the maximal activities of some glycolytic and citric acid cycle enzymes and glutaminase in mucosa of the small intestine of the rat. Biochem J 206, 169-172.

Buts JP, Vijverman V, Barudi C, De Keyser N, Maldague P \& Dive C (1990) Refeeding after starvation in the rat: comparative effects of lipids, proteins and carbohydrates on jejunal and ileal mucosal adaptation. Eur J Clin Invest 20, 441-452.

Butzner JD \& Gall DG (1990) Impact of refeeding on intestinal development and function in infant rabbits subjected to proteinenergy malnutrition. Pediatr Res 27, 245-251.

Cheah SH, Ch'ng SL, Husain R \& Duncan MT (1990) Effects of fasting during Ramadan on urinary excretion in Malaysian Muslims. Br J Nutr 63, 329-337.

Dou Y, Gregersen S, Zhao J, Zhuang F \& Gregersen H (2001) Effect of re-feeding after starvation on biomechanical properties in rat small intestine. Med Eng Phys 23, 557-566.

El Ati J, Beji C \& Danguir J (1995) Increased fat oxidation during Ramadan fasting in healthy women: an adaptative mechanism for body weight maintenance. Am J Clin Nutr 62, 302-307.

Farooq N, Yusufi ANK \& Mahmood R (2004) Effect of fasting on enzymes of carbohydrate metabolism and brush border membrane in rat intestine. Nutr Res 24, 407-416.

Fedail SS, Murphy D, Salih SY, Bolton CH \& Harvey RF (1982) Changes in certain blood constituents during Ramadan. Am J Clin Nutr 36, 350-353.

Fingerhut B, Ferzola R, Marsh WH \& Miller AB Jr (1966) Automated methods for blood glucose and urea with adaptation or simultaneous determination. Clin Chem 12, 570-576.

Frost G \& Pirani S (1987) Meal frequency and nutritional intake during Ramadan: a pilot study. Hum Nutr Appl Nutr 41, $47-50$.

Geyra A, Uni Z \& Sklan D (2001) The effect of fasting at different ages on growth and tissue dynamics in the small intestine of the young chick. Br J Nutr 86, 53-56.

Glossmann H \& Neville DM (1972) $\gamma$ Glutamyl transferase in kidney brush border membranes. FEBS Lett 19, 340-344. 
Goldmann DR, Schlesinger H \& Segal S (1976) Isolation and characterization of the brush border fraction from newborn rat renal proximal tubule cells. Biochim Biophys Acta 419, 251-260.

Gumaa KA, Mustafa KY, Mahmoud NA \& Gader AMA (1978) The effects of fasting in Ramadan 1. Serum uric acid and lipid concentrations. Br J Nutr 40, 573-581.

Hallack MH \& Nomani MZ (1988) Body weight loss and changes in blood lipid levels in normal men on hypocaloric diets during Ramadan fasting. Am J Clin Nutr 48, 1197-1210.

Holt PR \& Yeh KY (1992) Effects of starvation and refeeding on jejunal disaccharidase activity. Dig Dis Sci 37, 827-832.

Hubscher G \& Sherrat HAS (1962) Oxidation and glycolysis in subcellular fractions from small intestinal mucosa. Biochem J 84, 24.

Husain R, Duncan MT, Cheah SH \& Ch'ng SL (1987) Effects of fasting in Ramadan on tropical Asiatic Moslems. Br J Nutr 58, 41-48.

Kempson SA, Kim JK, Northrup TE, Knox FG \& Dousa TP (1979) Alkaline phosphatase in adaptation to low dietary phosphate intake. Am J Physiol 237, E465-E473.

Kessler M, Acuto O, Storelli C, Murer H, Muller M \& Semenza G (1978) A modified procedure for the rapid preparation of efficiently transporting vesicles from small intestinal brush border membranes. Their use in investigating some properties of D-glucose and choline transport systems. Biochim Biophys Acta 506, $136-154$.

Kornberg A (1955) Lactic dehydrogenase of muscle. In Methods in Enzymology, vol. 1, pp. 441-443 [SP Colowick and NO Kaplan, editors]. New York: Academic Press.

Kotler DP, Kral JG \& Bjorntorp P (1982) Refeeding after a fast in rats: effects on small intestinal enzymes. Am J Clin Nutr 36, 457-462.

Leiper JB, Molla AM \& Molla AM (2003) Effects on health of fluid restriction during fasting in Ramadan. Eur J Clin Nutr 57, $\mathrm{S} 30-\mathrm{S} 38$.

Lowry OH, Rosebrough NJ, Farr AL \& Randall RJ (1951) Protein measurement with Folin phenol reagent. J Biol Chem 193, $265-275$.

Maislos M, Abou-Rabiah Y, Iordash S \& Shany S (1998) Gorging and plasma HDL-cholesterol - the Ramadan model. Eur J Clin Nutr 52, 127-130.

Malhotra A, Scott PH, Scott J, Gee H \& Wharton BA (1989) Metabolic changes in Asian Muslim pregnant mothers observing the Ramadan fast in Britain. Br J Nutr 61, 663-672.

Martinkova A, Lenhardt L \& Mozes S (2000) Effect of neonatal MSG treatment on day-night alkaline phosphatase activity in rat duodenum. Physiol Res 49, 339-345.

Martins MJ, Hipolito-Reis C \& Azevedo I (2001) Effect of fasting on rat duodenal and jejunal microvilli. Clin Nutr 20, 325-331.

Mayhew TM (1987) Quantitative ultrastructural study on the responses of microvilli along the small bowel to fasting. J Anat 154, 237-243.

Meyer AH, Kornberg A, Grisolia S \& Ochoa S (1948) Enzymic mechanism of oxidation reactions between malate or isocitrate and pyruvate. J Biol Chem 174, 961-977.
Nomani MZA, Hallack MH, Nomani S \& Siddiqui IP (1989) Changes in blood urea and glucose and their association with energy containing nutrients in men on hypocaloric diets during Ramadan fasting. Am J Clin Nutr 49, 1141-1145.

Ochoa S (1955a) Isocitrate dehydrogenase system (TPN) from pig heart. In Methods in Enzymology, vol. 1, pp. 699-704 [SP Colowick and NO Kaplan, editors]. New York: Academic Press.

Ochoa S (1955b) Malic enzyme from pigeon liver and wheat germ. In Methods in Enzymology, vol. 1, pp. 739-747 [SP Colowick and NO Kaplan, editors]. New York: Academic Press.

Roky R, Houti I, Moussamih S, Qotbi S \& Aadil N (2004) Physiological and chronobiological changes during Ramadan intermittent fasting. Ann Nutr Metab 48, 296-303.

Saito M, Murakami E, Nishida Y, Fujisawa Y \& Suda M (1976) Circadian rhythms of digestive enzymes in the small intestine of rat. II. Effects of fasting and refeeding. J Biochem (Tokyo) 80, 563-568zz.

Shakespeare P, Srivastava LM \& Hubscher G (1969) Glucose metabolism in the mucosa of the small intestine: the effect of glucose on hexokinase activity. Biochem J 111, 63-67.

Shen CS \& Mistry SP (1979) Effects of fasting and refeeding on hepatic and renal gluconeogenic enzymes in chicken. Poult Sci 58, 890-895.

Shonk CC \& Boxer GE (1964) Enzyme patterns in human tissues. I. Methods for determination of glycolytic enzymes. Cancer Res 24, 709-721.

Shull KH, Ashmore J \& Mayer J (1956) Hexokinase, glucose-6-phosphatase and phosphorylase levels in hereditarily obese, hyperglycemic mice. Arch Biochem Biophysics 62, 210-216.

Stifel FB, Herman RH, Rosensweig NS \& Zakim D (1969) Dietary regulation of glycolytic enzymes. III. Adaptive changes in rat jejunal pyruvate kinase, phosphofructokinase, fructosediphosphatase and glycerol-3-phosphate dehydrogenase. Biochim Biophysics Acta 184, 29-34.

Stifel FB, Rosenweig NS, Zakim D \& Herman RH (1968) Dietary regulation of glycolytic enzymes. I. Adaptive changes in rat jejunum. Biochim Biophysics Acta 170, 221-227.

Szczepanska-Konkel M, Yusufi ANK \& Dousa TP (1987) Interaction of $\left[{ }^{14} \mathrm{C}\right]$ phosphonoformic acid with renal cortical brush border membrane. J Biol Chem 262, 8000-8010.

Tausky HH \& Shorr EA (1953) A microcolorimetric method for the determination of inorganic phosphorus. J Biol Chem 202, 675-685.

Toda M \& Morimoto K (2000) Effects of Ramadan fast on health of Muslims. Nippon Eiseigaku Zasshi 54, 592-596.

Yucel A, Degirmenci B, Acar M, Albayrak R \& Haktanir A (2004) The effect of fasting month of Ramadan on the abdominal fat distribution: assessment by computed tomography. Tohoku J Exp Med 204, 179-187.

Yusufi ANK, Low MG, Turner ST \& Dousa TP (1983) Selective removal of alkaline phosphatase from renal brush border membrane and sodium dependent brush border membrane transport. J Biol Chem 258, 5695-5701.

Zlatkis A, Zak B \& Boyle AJ (1953) A new method for the direct determination of serum cholesterol. J Lab Clin Med 41, 486-492. 